\title{
The Effect of Using Out-of-School Learning Environments in Science Teaching on Motivation for Learning Science
}

\author{
Halil İbrahim YILDIRIM* \\ Department of Science Education, Gazi University, Ankara, Turkey \\ ORCID: 0000-0002-8836-8349
}

Article history

Received:

23.11.2019

Received in revised form: 27.01.2020

Accepted:

05.02.2020

Key words:

Out-of-school learning environments, motivation for science learning, science teaching
This study aims to determine the effect of using out-of-school learning environments in science teaching on motivation for learning science. It is a quasi-experimental study and it has been designed as pre- and posttest experimental study. The study was carried out with seventh grade students enrolled in a secondary school in the city centre of a metropolis of Turkey in 2018 within a period of 20 weeks. There were 28 students in the control group and 28 students in the experiment group. Students' motivation for science learning was evaluated using the Motivation Scale for Science Learning. The scale was used as pretest before the study, post-test at the end of the study, and follow-up test 12 weeks after the study. In the research, the application step was carried out by the science teacher and the researcher. In the control group, science teaching process was performed in accordance with the present science curriculum. Out-of-school learning environments related to the objectives of the current science teaching were used for the experiment group during the science teaching. The students in the experiment group visited out-of-school learning environments like nature trips, botanic parks, science fairs, science museums, natural history museums, the observatory, anatomy exhibitions, and energy parks for the subjects that were taught to them. It was found in the study that using out-of-school learning environments in science teaching had a significant effect in developing students' motivation for learning science. Based on this finding, formal education of science students can be supported with out-of-school learning environments.

\section{Introduction}

Today, learning and teaching have become a part of a lifelong process that use schools' resources and other potential resources in the immediate circle. To that end, learning environments that can provide information in an easy, understandable and pleasant way are needed. In this context, because out-of-school environments are associated with classes, they allow students to individually interact with actual objects, and develop positive attitudesvalues and novel viewpoints acquiring knowledge of permanent nature. In this regard these environments can be turned into very effective learning environments, that is, out-of-school learning environments (OSLE). Effective learning can be ensured with students' inclusion in such trips to these environments that are well-planned for achieving certain objectives. Thus, 
the curriculum should be associated with OSLE and a bridge should be built between classes and OSLE (Bakioğlu, 2017; Bozdoğan, 2007; Bozdoğan, 2018; Laçin Şimşek, 2011; Yıldırım, 2018a). Also, Çığrık (2016), Laçin Şimşek, (2011), Stocklmayer, Rennie and Gilbert (2010), Yıldırım (2018a), Yıldırım (2018b) emphasized that formal learning-teaching ought to be supported with OSLE.

\section{Out-of-school learning environments (OSLE)}

OSLE evoke informal, unstructured, and random learning first. However, these are in fact planned, and systematic activities as well as trips organized for certain aims out of the school walls (Laçin Şimşek, 2011). OSLE comprise both formal and informal education and it stands just where they intersect (Bakioğlu, 2017; Bozdoğan, 2007). According to the relevant literature, learning environments are divided into three groups that are formal, non-formal, and informal. OSLE are included in non-formal group as they are planned and realized out of the school under the guidance of an instructor. These environments include museums, zoos, botanical gardens, planetariums, national parks, camping activities in nature, aquariums, plants, etc. (Hofstein \& Rosenfeld, 1996; Laçin Şimşek, 2011; Ministry of National Education [MNE], 2013; 2017; Türkmen, 2010; Y1ldırım, 2018a). Salmi (1993) defined out-of-school education as education realized simultaneously with the curriculum during the schooleducation period and its scope encompasses any institutions or environments out of the physical school premises. OSLE can also be defined as learning environments where students have an active role, learn by doing, and places that draw their attention as they are out-ofschool environments and allow them to experience course subjects in real life situations (Y1ldırım, 2018a). Thus, out-of-school learning activities constitute a process related with formal education that let learning environment goes out of the classroom to achieve objectives and outcomes of the relevant class (Yavuz Topaloğlu, 2016). The aim of out-of-school education is to support personal development of students outside the school based on their age, interest, demands, and needs at the same time in accordance with the gains in the curriculum (Binbaşığlu, 2000).

Out-of-school science learning environments can be defined as learning environments which are simply out-of-school, that arouse students' interest, excitement, and curiosity toward science to learn about the phenomena-cases-concepts in daily life reflecting what is covered in science classes; which let them keep their attitudes and motivation alive towards science enabling them to learn, relate and explain by discovering science-related concepts through everyday activities. These also aim at teaching by helping learners discover concepts and cases, foster investigating, and facilitate observing and thusly support formal science education through programs developed for science teaching (Bozdoğan, 2018; National Research Council, 2009; Laçin Şimşek, 2011; Yıldırım, 2018a).

The study results from the related literature show that OSLE contribute to students' academic achievement (Randler, Kummer \& Wilhelm, 2012), interest-curiosity (Behrendt \& Franklin, 2014; Falk \& Needham, 2011; Falk, Needham, Dierking \& Prendergast, 2014), attitudes (Ramey-Gassert, Walberg \& Walberg, 1994; Y1ldırım, 2018a), motivation (Ramey-Gassert et al., 1994), research skills (Katz et al., 2011), communication-social skills (Smith, Steel \& Gidlow, 2010; Sözer \& Oral, 2016), scientific process skills (Bodur, 2015), learning (Bozdoğan, Okur \& Kasap, 2015; Guisasola, Morentin \& Zuza, 2005; Guisasola, Solbes, Barragues, Morentin \& Moreno, 2009); allow to have self-experience; and facilitate interrelate between real life and knowledge taught at school (Chin, 2004). OSLE enable students to use and structure scientific process skills, concretize concepts in the science 
course, and provide first hand sources for the most appropriate learning environment (Erten, 2016).

Although these environments provide students with rich learning opportunities during their education, it does not warranty that they can always reach learning-related targets. Furthermore, out-of-school learning may have its own limitations, too (Griffin, 2004). Therefore, OSLE should be used as education environments that include both entertainment and learning together which take place in a planned and structured way to achieve the specific course goals outside school. This is because OSLE are places where activities are organized within the scope of the course targets and gains in the curriculum, but they are not the places where unstructured learning randomly occurs without any prior planning (Laçin Şimşek, 2011). Thereupon, planning of trips is one of the most important issues that should be considered within the frame of out-of-school trips that will be organized (Bozdoğan, 2012; Bozdoğan, 2018; Ertaş, Şen \& Parmaksızoğlu, 2011; Yıldırım, 2018a). Teachers indeed have the most crucial role in planning trips. A study conducted by Kete and Horasan (2013) reported that teachers have a key role in using OSLE to support the teaching process.

In light of the aforementioned, there are processes and official procedures that should be taken into consideration by teachers before, during and after trips that are organized for outof-school learning purposes to realize the objectives of a class. Before trips which are organized to attain the objectives of the curriculum, teachers should plan OSLE where the trips will be organized, prepare relevant work sheets, cooperate with the school and get permission from parents and directory of the school, make appointments with OSLE for visits, plan guidance services, and inform both students and their parents accordingly. Teachers should visit OSLE on their own before trips with their students, contact with guides, share information with guides about the class level, and the subjects to be taught to students. Also, transportation to the destination, meals of the students, and accommodation, provided the destination is out of town, should be well-planned. During the trip to OSLE, students should be encouraged to get actively engaged in experiencing real life situations aimed at the course objectives through touches and trials in accompany with the guides. Also, the students should be asked questions regarding the activities, and be allowed to have some free time activities. The students should be distributed work sheets and should be encouraged to answer the questions in the work sheet by discovering, observing and testing. They should be allowed to learn by having fun and socializing without being charged with lots of responsibilities during the trips. After the trip, the experiments that the students have conducted and the materials they have observed should be connected with the educational gains and these experiences should be integrated into in-class learning environment. The trip and observation forms should be checked, and the students should be asked questions about the trip. The students should be supported to share their experiences from the trip and to hold a discussion on the activities done to reach generalizations. On the condition that any problems arise during the trip, the reasons behind them should be investigated afterwards as whole class and necessary measures should be taken to prevent such troubles in future trips. The photographs and videos taken during the trip can be exhibited. Parents of the students should be informed about the activities done during the trip (Bozdoğan, 2018; Ertaş \& Şen, 2017; Laçin Şimşek, 2011; Y1ldirım, 2018a).

\section{Motivation during Teaching and its Importance}

Motivation, a dependent variable of the study, is one of the important affective characteristics that have impacts on learning-teaching (Lazowski \& Hulleman, 2016; Y1ldırım 
\& Karataş, 2018). Motivation can be defined as the power that helps people to focus on a certain objective, sets them into motion, assists in realizing a certain behaviour, stimulates and directs actions to attain goals, maintains intellectual and/or physical effort accordingly, and provides continuance of these actions mentioned (Selçuk, 2015; Topçuoğlu Ünal \& Bursalı, 2013; Y1ldırım \& Karataş, 2018). Previous studies indicate that motivation is one important affective factor in science courses. Students need to be motived to better learn scientific concepts, to promote success in science courses, and to develop scientific process skills. Motivation is an influential concept in learning, and directly affects student success in science courses (Uzun \& Keleş, 2012). It aids students in such areas as science in particular where they have cognitive difficulties in experiencing meaningful learning (Güvercin, Tekkaya \& Sungur, 2010). In fact, it is of crucial importance for the overall learning process and realization of learning. Thus, instructors should be aware of the importance of motivation, consider affective factors like motivation during educational processes, and create appropriate learning environments for students to increase students' affective properties like motivation for learning (Yıldırım \& Karataş, 2018). Hence it is important to support students' formal teaching process with learning-teaching environments like OSLE to increase their motivation.

\section{Significance and Justification of the Study}

Training individuals who have skills of being able to read and understand, use what has been learned in daily life, produce, and catch up with the era is related with realizing education and training in the most real-like educational environments (Bakioğlu, 2017; Cantürk Günhan \& Başer, 2008). Formal learning within the classroom is usually away from reality, deprived of experiences, carried out mostly with an emphasis on symbols and statements, and without establishing interaction with tangible and real objects (Laçin Şimşek, 2011). Bakioğlu (2017) stated that offering education within the borders of the school means that students will not benefit from the process to the full extent adding that OSLE should be embraced in that sense.

Science classes which themselves are the essence of life are usually limited with the classroom environment. However, real life that possesses many phenomena, events, and concepts that occur outside the classroom. In parallel to that, any place with which people interact outside the classroom can be used as a source to learn science (Tatar \& Bağrıyanık, 2012). It is contradictory that instructors teach science within the classroom only, yet knowledge mostly originates from the nature itself. It would then be fair to say that the courses offered to students out-of-school environments are valuable for them. Such environments build a bridge between school and natural environment and allow students to make use of their potential in the best way (Türkmen, 2018). For this reason, it is important to shed light on out-of-school environments, teach students science, and make use of out-ofschool environments for learning and teaching widely (Bakioğlu \& Karamustafaoğlu, 2014).

As students would want to have a more active role only in their fields of interest, activities should be planned and implemented in a way to draw their attention and arouse their curiosity for each subject in the education program. The most permanent learning occurs when students themselves do, see, and experiment with things. In line with that, it is easier for the student to learn by seeing, doing, and experiencing than by solely listening, reading, and writing (Akcan, 2010). In brief, it is quite important that in-school activities be supported with out-of-school activities in science courses (Atmaca, 2012). Taking into account that the primary goal of education is to prepare individuals for life in the best possible way, out-of-school activities are extremely important for students to learn by observing and experiencing life in a student- 
centered approach (Taşoğlu, 2010). In this context, out-of-school education, offered beyond the walls of classrooms, becomes more and more important (Çebi, 2018).

It is necessary to include OSLE in education as well as in-class practices to realize meaningful and permanent learning and train science literate individuals (MNE, 2013). Stocklmayer \& Gilbert (2003) stated that besides formal education, out-of-school education is also important to train science literate individuals who can transfer their knowledge of science and associate it with daily life. This is because informal learning is based on learning processes focused on experience, research, and application that improve literacy levels pertaining to science (Fried Hoffer, 2007). Thus, formal education should be supported by OSLE that address distinctive characteristics and can contribute to enriching the teaching environment, that draw attention to courses, that ensure learning by having fun, that pave the way for learning the subjects more easily through experiencing them in real life, and all these should not be limited with the classroom (Y1ldirım, 2018a). Based on the above-mentioned information, this study gains importance as it investigates the effect of OSLE on motivation in science classes that are directly related with real life. Considering that motivation is one important affective factor for learning along with success and students should be motivated to learning during their education (Yıldırım \& Karataş, 2018), studies investigating the effect of learning environments on motivation will make a contribution to the relevant literature.

The literature mostly includes studies concentrating upon the effect of trips to one or several OSLE on the development of students' cognitive and affective skills, or other short-term studies investigating students' opinions at the end of such trips. This study differs from other studies in that it includes visits to several OSLE associated with the objectives of the curriculum, has an adequate application period to make sure the affective development of students, and investigates the change in motivation to learn science.

Examining the studies in the literature (Bodur, 2015; Çebi, 2018; Çı̆̆rık \& Özkan, 2016; Güler, 2011; Kulalıgil \& Bağ, 2014; Taşdemir, Kartal \& Kuş, 2012); one of the remarkable results is that an affective property which was expected to change in the long term apparently realized in such a short time of 3-4 weeks and with a few visits to OSLE. In addition, the studies did not examine whether the change occurring in an affective property was permanent, namely whether OSLE had a long-term effect on affective properties or not. Majority of the studies made no mention of utilizing a learning-teaching approach during visits to OSLE, either. Besides, the studies did not explain the correlations between OSLE visited and acquisitions in the curriculum in detail. These are the limitations of the studies on OSLE. Taking these limitations into consideration; it is of prime importance to keep this study long enough to enable the development of an affective property like motivation, to examine whether the change taking place in relation to motivation is permanent, to explain the correlations between OSLE visited and acquisitions in the curriculum, to visit OSLE regarding every subject being taught, to use a learning-teaching model including introduction, development, conclusion and evaluation via Prediction-Observation-Explanation (POE) technique in OSLE and to explain the applications in detail.

\section{Aim of the Research}

This study aims to determine the impact of using OSLE on motivation during science teaching process. The following questions seek answers in this respect. 
(1) Is the difference between motivation levels of the students in the experiment group taking part in OSLE for science learning at the beginning, at the end, and 12 weeks after the experiment significant?

(2) Is the difference between motivation levels of the students in the control group to whom the 2018-year science curriculum was applied at the beginning, at the end, and 12 weeks after the study significant?

(3) Is the difference between motivation levels of the students in the experiment group who were taken to OSLE in science classes and in the control group to whom the 2018-year science curriculum was applied at the beginning, at the end and 12 weeks after the study significant?

\section{Method}

\section{Research Design}

This is a quasi-experimental research as the seventh-grade students of a secondary school in Turkey were not assigned to groups by drawing lots, instead, they were included in the study without making any changes in their classes. It was also designed as an experimental study with pre-test and post-test and control group because the motivation scale was administered before the experiment (pre-test), at the end of the experiment (post-test), and 12 weeks after the experiment (follow-up test) (Büyüköztürk, Kılıç Çakmak, Akgün, Karadeniz \& Demirel, 2016).

\section{Research Group}

The research group is comprised of seventh-grade students in a secondary school in a central district of a metropolis in Turkey in 2018. The study was conducted with 56 students: 28 students in the experiment group and 28 in the control group. Two $7^{\text {th }}$ grade classes with close grade point averages for the science course were included in this study. Which class would constitute the experimental or the control group was determined by drawing lots.

The sampling method was appropriate for the study considering that the researcher included the instructors and students with whom he could collaborate easily in OSLE visits, who he could direct, whose classes he could follow up and visit easily and who he could train in science teaching (Büyüköztürk et al., 2016).

\section{Participant Characteristics}

All the students received their education in the central district of a metropolis in the same school in 2018. They all lived in the city centre. There were 14 females and 14 males in the experiment group and 15 females and 13 males in the control group. The numbers of the students who studied science for over 5 hours, 5 hours, 4 hours, 3 hours, 2 hours, and 1 hour a week on average are 2, 5, 6, 7, 5 and 3 in the experimental group and they were 3, 6, 6, 5, 5 and 3 in the control group, respectively. As it can be seen, gender distribution of the groups and the time spent for studying science are similar.

\section{Data Collection Tools}

The Motivation Scale for Science Learning that was developed by Dede and Yaman (2008) was used to measure students' motivation for science learning. The scale included 23 items and was rated on a five-point Likert scale with "strongly disagree" and "strongly 
agree". An expert was consulted for the content validity during the development of the scale and it was found to have content validity. Construct validity was ensured by exploratory factor analysis. Reliability analysis of the scale was made, and the Cronbach's alpha coefficient was found to be 0.80 . Below are the examples of some items in the scale:

“6. I like searching for answers of science problems."

“18. In group work, I do not care about others' ideas.” (Dede \& Yaman, 2008).

The positive items in the scale were scored as "strongly agree $=5$ ", "agree=4", "somewhat agree $=3$ ", "disagree $=2$ ", and "strongly disagree $=1$ ". However, the negative items were scored as "strongly agree=1", "agree=2", "somewhat agree=3", "disagree=4", and "strongly disagree $=5$ ". The lowest score from the motivation scale was 23 and the highest was 115 . The students' total score from the scale shows their motivation levels for science learning. Reliability of the scale was first measured by administering the scale to 188 seventh grade students who were not included in the sample of the study and the Cronbach's alpha coefficient was found to be 0.86. A reliability score higher than 0.70 shows that the motivation scale is reliable (Büyüköztürk, 2016).

\section{Data Analysis}

The data were analysed using SPSS 22 software. Kurtosis and Skewness coefficients and Shapiro Wilk analysis were used to determine normal distribution of the data. The results are shown in Table 1.

Table 1. Descriptive analysis for science course grades and the pre-, post-, and follow-up tests for motivation

\begin{tabular}{llllll}
\hline Test & Group & $\mathrm{N}$ & Skewness & Kurtosis & Shapiro-Wilk (p) \\
\multirow{2}{*}{ Pre-test } & Control & 28 & 0.06 & -1.01 & 0.47 \\
& Experiment & 28 & -0.27 & -0.81 & 0.50 \\
\hline \multirow{2}{*}{ Posttest } & Control & 28 & -0.29 & -0.69 & 0.64 \\
& Experiment & 28 & -0.28 & -0.60 & 0.41 \\
\hline \multirow{2}{*}{ Follow-up } & Control & 28 & -0.32 & -0.99 & 0.18 \\
Test & Experiment & 28 & -0.08 & -0.62 & 0.56 \\
\hline \multirow{2}{*}{ Science } & Control & 28 & 0.28 & -0.77 & 0.57 \\
course note & Experiment & 28 & 0.12 & -0.90 & 0.60 \\
\hline
\end{tabular}

The science course grades and the scores on the pre-, post-, and follow-up tests for motivation for science learning in both groups have a normal distribution considering that skewness and kurtosis and coefficients are at the ranges of $-1.5--+1.5$ as shown in Table 1. Therefore, parametric tests were used for data analysis. Independent samples t-test was used to compare both the control and experiment groups' science course grades and scores on the pre-, post-, and follow-up tests. One-way ANOVA was used to compare the scores of the experiment group on the pre-, post-, and follow-up tests for repeated measures. Bonferroni analysis was used to find whether the difference was significant. The significance level of 0.05 was set in analysing the results. Homogeneity of the variances was considered during analyses (Büyüköztürk, 2016). Eta Squared ( $\eta 2)$ was used to measure the effect size. In the evaluation of $\eta 2$, the effect size was interpreted as follows; $0.01<\eta 2<0.06$ : small, $0.06 \leq \eta 2<0.14$ : moderate, $0.14 \leq \eta 2$ : big (Cohen, 1988). 


\section{Application of the Research}

The research was carried out with seventh grade students in a private secondary school in a central district of a metropolis in Turkey in 2018. The experimental activity phase was conducted by the same science teacher in both groups. Implementation period of the study was determined as 20 weeks considering the allocated time for the science curriculum shown in Table 2. At the beginning of the experiment, a motivation scale was used as pre-test to determine students' motivation levels.

No experiment was carried out with the control group during science courses and the students were taught in accordance with the current gains in the science curriculum. On the other hand, in the experiment group, OSLE in relation to the current acquisitions specified in the science curriculum were used.

The trips to be organized by the school directory were planned before the academic period started according to the objectives of the OSLE and the subjects to be covered during the research. All students in the experiment group were appointed to the Science and Technology Club and the visits were made within the scope of the club activities of science. In this way the other courses were believed not to be affected by these trips since the bus trip was made within the duration of the club course. The group visited eight OSLE within 20 weeks with the support of the school. A trip was organized to Şehit Mehmet Alan Energy Park and Şehit Cuma Dağ Natural History Museum on the same day. Additionally, a science fair in a school in the near vicinity was visited, the sky was observed in an open space and a park was visited for the purpose of taking a nature trip.

OSLE aim to realize educational targets in a curriculum out-of-school environment, are selected with respect to these targets, organized in a planned and structured way, and allow learning by drawing learner attention while having fun. In this context there are some steps in the preparation of the trips to be organized by the instructors in OSLE i.e. the ones before, during, and after the trip, as these trips are different from the ordinary ones. The first step is to determine the out-of-school environments to be visited. The OSLE were selected in accordance with the gains of the science curriculum. Some of these gains and the out-ofschool environments visited are shown in Table 2.

Table 2. Relationship of the objectives of seventh grade science curriculum with the OSLE visited

\begin{tabular}{|c|c|c|c|}
\hline Subject & $\begin{array}{l}\text { Samples for the objectives in the } \\
\text { curriculum }\end{array}$ & Environments visited & $\begin{array}{l}\text { Relationship between } \\
\text { the acquisitions and } \\
\text { the environments } \\
\text { visited }\end{array}$ \\
\hline $\begin{array}{l}\text { Solar System } \\
\text { and Beyond }\end{array}$ & $\begin{array}{l}\text { Explain the structure of telescope and its } \\
\text { functions. } \\
\text { Make inferences about the importance of } \\
\text { the telescope in the development of } \\
\text { astronomy. } \\
\text { Prepare and present an ordinary telescope } \\
\text { model. } \\
\text { Explain stars, galaxies and universe. }\end{array}$ & $\begin{array}{l}\text { Society-Science- } \\
\text { Application-Research } \\
\text { Center-Planetarium, } \\
\text { Kreiken Observatory, } \\
\text { Observation of Sky }\end{array}$ & $\begin{array}{l}\text { Analyzes the } \\
\text { structure of the } \\
\text { telescope. Observes } \\
\text { the stars, the moon, } \\
\text { the sun, and the } \\
\text { planets. }\end{array}$ \\
\hline $\begin{array}{l}\text { Power } \\
\text { Energy }\end{array}$ & $\begin{array}{l}\text { Name the gravity force as weight which } \\
\text { impacts the mass. } \\
\text { Explain gravitation as mass on the basis } \\
\text { of heavenly bodies. } \\
\text { Explain that physical work is related with } \\
\text { applied power and progression. }\end{array}$ & $\begin{array}{l}\text { Society-Science- } \\
\text { Application-Research } \\
\text { Center, } \\
\text { Polatl Municipality } \\
\text { Science Center } \\
\text { Şehit Mehmet Alan }\end{array}$ & $\begin{array}{l}\text { Observe the mass, } \\
\text { gravitational pull, } \\
\text { physical work, } \\
\text { energy, kinetic and } \\
\text { potential energy, } \\
\text { energy }\end{array}$ \\
\hline
\end{tabular}




\begin{tabular}{|c|c|c|c|}
\hline & $\begin{array}{l}\text { Correlate energy with work and classify it } \\
\text { as kinetic and potential energy. } \\
\text { Deduce that kinetic and potential energy } \\
\text { is conserved by their transformation to } \\
\text { each other. }\end{array}$ & Energy Park & $\begin{array}{l}\text { transformation, and } \\
\text { energy conservation. }\end{array}$ \\
\hline $\begin{array}{l}\text { Reproduction- } \\
\text { Growth- } \\
\text { Development } \\
\text { in Creatures }\end{array}$ & $\begin{array}{l}\text { Explain species of reproduction in } \\
\text { animals and plants by comparison. } \\
\text { Explain growth and development process } \\
\text { in animals and plants with examples. } \\
\text { Explain main factors influencing growth } \\
\text { and development in animals and plants. }\end{array}$ & $\begin{array}{l}\text { Şehit Cuma Dağ } \\
\text { Natural History } \\
\text { Museum, } \\
\text { Anatomy Exhibition } \\
\text { Hall and Insect } \\
\text { Festival School, } \\
\text { Botanic Park, } \\
\text { A Nature Trip in a } \\
\text { School Garden and a } \\
\text { Park Around the } \\
\text { School }\end{array}$ & $\begin{array}{l}\text { Observe reproduction } \\
\text { of species, growth } \\
\text { and development } \\
\text { process, steps of } \\
\text { plants, and } \\
\text { pollination in animals } \\
\text { and plants. }\end{array}$ \\
\hline
\end{tabular}

\begin{tabular}{llll}
\hline & $\begin{array}{l}\text { Explore that light is absorbed by the } \\
\text { matter as they interact. }\end{array}$ & \\
Interaction of $\begin{array}{l}\text { Deduce that white light consists of } \\
\text { combination of all colours. }\end{array}$ & $\begin{array}{l}\text { Society-Science- } \\
\text { Application-Research }\end{array}$ & $\begin{array}{l}\text { Observes interaction } \\
\text { of light with matter } \\
\text { and the types of glass } \\
\text { Matter with }\end{array}$ \\
& $\begin{array}{l}\text { Observe all glass types and provide } \\
\text { examples of their area of usage. }\end{array}$ & $\begin{array}{l}\text { Center, } \\
\text { Science Fair }\end{array}$ \\
& $\begin{array}{l}\text { Provide examples of the area of usage of } \\
\text { lens in daily life and technology. }\end{array}$ & & \\
\hline
\end{tabular}

The students in the experiment group participated in the trips to OSLE, shown in Table 2, under the guidance of the researcher and their instructor. The necessary permissions were obtained from the parents in collaboration with the school management before the trips. Appointments for trips to OSLE were made, guides were selected, the destinations were visited for gathering information about the places and educational activities to be carried out were determined before the trips. Also, the guides were informed about the class levels, subjects to be taught and teaching methods. The transportation, food, and beverages were planned for these trips. Work sheets and observation forms were prepared to be distributed to the students. Science teaching period in out-of-school environments was designed through introduction, development, conclusion, and evaluation phases.

In the introduction phase, the students in the experiment group were distributed brochures about OSLE before the trip, and they were motived to learning by being attracted to the subjects. Furthermore, their readiness and prior knowledge about the subject were determined by brainstorming method and prior knowledge tests. To draw the students' to attention to the subjects and make them motivated, the students were allowed for 10 minutes to go around OSLE. In the development phase, the students did activities regarding the subjects by experiencing with the participation of the guide and science teacher. The PredictionObservation-Explanation technique was used in the activities. The students were asked to write down their expectations from the activity before the study, their observations during the activity, and explain whether their expectations and observations were consistent at the end of the activity on the work sheets. Much attention was given for the students to do free time activities during the trip. In the conclusion phase, first, the students were asked to explain the target concepts and subjects at the end of the activities, and then the guide and instructor explained these concepts and subjects to them. Furthermore, students' impressions about each activity, which was conducted after the visits to OSLE, were shared, discussed and generalized in the classroom in this phase. In the evaluation phase, the students' development was evaluated using traditional-alternative assessment-evaluation tools in the classroom. The trips to OSLE took around 4 to 4.5 hours for science courses (160 minutes a week) and 
Science and Technology Club courses (80 minutes a week). The following week after the trip, the result (sharing, discussing, generalizing) and evaluation phases were addressed in four science courses. A post-test for motivation scale was used at the final step of the experiment, and a follow-up test was used to determine whether the change in motivation 12 weeks after the experiment was retained.

\section{Findings}

The students' success in learning science and their motivation equivalence for science learning at the beginning of the experiment were investigated and the results were shown in Table 3 and Table 4.

Table 3. Independent samples t-test analysis regarding science course grades

\begin{tabular}{lllllll}
\hline Group & $\mathrm{N}$ & $\overline{\mathrm{X}}$ & $\mathrm{S}$ & $\mathrm{df}$ & $\mathrm{t}$ & $\mathrm{p}$ \\
\hline Control & 28 & 75.04 & 11.99 & 54 & 0.05 & 0.96 \\
Experiment & 28 & 74.86 & 12.96 & & & \\
\hline
\end{tabular}

There was no significant difference between science course grades of the students in the control and experiment groups $\left(\mathrm{t}_{(54)}=0.05 ; \mathrm{p}>0.05\right)$. This finding shows that science course grades of the students in both groups were similar before the experiment.

Table 4. Independent samples t-test analysis regarding students' pre-test scores of motivation for science learning

\begin{tabular}{lllllll}
\hline Group & $\mathrm{N}$ & $\overline{\mathrm{X}}$ & $\mathrm{S}$ & $\mathrm{df}$ & $\mathrm{t}$ & $\mathrm{p}$ \\
\hline Control & 28 & 78.14 & 12.54 & \multirow{2}{*}{0} & \multirow{2}{*}{0.12} & 0.90 \\
Experiment & 28 & 77.75 & 11.60 & & & \\
\hline
\end{tabular}

As shown Table 4, no significant difference was found between the pre-test mean scores of the students in both groups regarding their motivation for science learning before the experiment $\left(\mathrm{t}_{(54)}=0.12 ; \mathrm{p}>0.05\right)$. This finding shows that the students in both groups had similar levels of motivation before the experiment.

Table 5. Independent samples t-test analysis regarding students' post-test scores of motivation for science learning

\begin{tabular}{|c|c|c|c|c|c|c|}
\hline Group & $\mathrm{N}$ & $\bar{x}$ & $S$ & $\mathrm{df}$ & $\mathrm{t}$ & $\mathrm{p}$ \\
\hline Control & 28 & 79.54 & 13.42 & \multirow{2}{*}{54} & \multirow{2}{*}{4.65} & \multirow{2}{*}{0.001} \\
\hline Experiment & 28 & 95.61 & 12.39 & & & \\
\hline
\end{tabular}

Table 5 shows that the experiment group had significantly higher post-test scores on motivation for science learning than the control group at the end of the experiment $\left(\mathrm{t}_{(54)}=\right.$ 4.65; $\mathrm{p}<0.05)$. The effect size higher than $\left(\eta^{2}=0.28\right) 0.14$ can be interpreted as a high effect size (Cohen, 1988).

Table 6. Independent samples t-test analysis regarding students' follow-up test scores of motivation for science learning

\begin{tabular}{lllllll}
\hline Group & $\mathrm{N}$ & $\overline{\mathrm{X}}$ & $\mathrm{S}$ & $\mathrm{df}$ & $\mathrm{t}$ & $\mathrm{p}$ \\
\hline Control & 28 & 79.07 & 11.91 & \multirow{2}{*}{54} & \multirow{2}{*}{4.69} & 0.001 \\
Experiment & 28 & 94.82 & 13.20 & & & \\
\hline
\end{tabular}


Table 6 shows that the experiment group had significantly higher follow-up test scores on motivation for science learning than the control group at the end of the experiment $\left(t_{(54)}=\right.$ $4.69 ; \mathrm{p}<0.05)$. That is to say, the students in the experiment group had higher motivation than the control group 12 weeks after the experiment. The effect size higher than $\left(\eta^{2}=0.29\right) 0.14$ can be interpreted as a high effect size (Cohen, 1988).

Table 7. Descriptive analysis of the control group's pre-, post-, and follow-up tests scores of motivation for science learning

\begin{tabular}{lllll}
\hline Test No & Test & N & $\bar{X}$ & S \\
\hline 1 & Pre & 28 & 78.14 & 12.54 \\
2 & Post & 28 & 79.54 & 13.42 \\
3 & Follow-up & 28 & 79.07 & 11.91 \\
\hline
\end{tabular}

Table 8. One-way ANOVA analysis for repeated measures of the control group's pre-, post-, and follow-up tests scores of motivation for science learning

\begin{tabular}{llllll}
\hline Source of Variance & Sum of Square & df & Mean Square & F & p \\
\hline Between Subjects & 12580.417 & 27 & 465.941 & & \\
Measurement & 28.167 & 2 & 14.083 & 2.162 & 0.13 \\
Error & 351.833 & 54 & 6.515 & & \\
Total & 12960.417 & 83 & & & \\
\hline
\end{tabular}

Table 7 and Table 8 show that there was no significant difference between the control group's pre-, post-, and follow-up tests scores of motivation for science learning $\left(\mathrm{F}_{(2-54)}=2.162\right.$; $\mathrm{p}>0.05)$. This finding shows that the students in the control group had motivation at similar levels before, after, and 12 weeks after the experiment.

Table 9. Descriptive analysis of the experimental group's pre-, post-, and follow-up tests scores of motivation for science learning

\begin{tabular}{llll}
\hline Test & $\mathrm{N}$ & $\overline{\mathrm{X}}$ & $\mathrm{S}$ \\
\hline Pre & 28 & 77.75 & 11.60 \\
Post & 28 & 95.61 & 12.39 \\
Follow-up & 28 & 94.82 & 13.20 \\
\hline
\end{tabular}

Table 10. One-way ANOVA analysis for repeated measures of experiment group's pre-, post, and follow-up tests scores of motivation for science learning

\begin{tabular}{lllllll}
\hline Source of Variance & $\begin{array}{l}\text { Sum } \\
\text { Square }\end{array}$ & of & Mean Square & F & p & $\begin{array}{l}\text { Significant } \\
\text { Difference }\end{array}$ \\
\hline Between Subjects & 11766.036 & 27 & 435.779 & & & Post-test \\
Measurement & 5702.000 & 2 & 2851.000 & & \multirow{2}{*}{ - } \\
Error & 718.000 & 54 & 13.296 & & 0.001 & $\begin{array}{l}\text { Pre-test, } \\
\text { Follow-up } \\
\text { Total }\end{array}$ \\
\hline
\end{tabular}

Table 9 and Table 10 show that there was no significant difference between experiment group's pre-, post-, and follow-up tests scores of motivation for science learning $\left(\mathrm{F}_{(2-54)}=\right.$ $214.421 ; \mathrm{p}<0.05)$. The Bonferroni analysis indicated that there were significant differences in favour of the post-test compared to the pre-test, and in favour of the follow-up test compared to the pre-test. This finding shows that motivation of the students in the experiment group was 
higher at the end and 12 weeks after the experiment than it was at the beginning. Also, the average of the follow-up test was lower, though not significant, than that of the post-test. This result shows that the students in the experiment group had motivation at similar levels at the end and 12 weeks after the experiment. These results show that OSLE had a significant effect on increasing students' motivation for science learning. The effect size higher than $(\eta 2=0.89)$ 0.14 can be interpreted as a high effect size (Cohen, 1988).

\section{Discussion, Results and Suggestions}

This research examined the impact of using OSLE in science teaching on motivation for science learning. In the beginning of the study, students in the control and experimental group had similar levels of motivation to learn science. By the end of the study and 12 weeks after completing the study, the experimental group had significantly higher levels of motivation than the control group. The effect size values were also high. These findings show that OSLE in science teaching are more effective in improving motivation for science learning than the courses in the curriculum applied to the control group.

In the study process, no significant improvement was observed in motivation scores of the control group, while a significant improvement was made in motivation scores of the experimental group and this improvement was retained by the end of the 12 -week period. Also, effect size of the experimental procedure in the experimental group was high. These findings show that visits made to OSLE support the development of students' motivation for science learning and have a great effect on maintaining this development. It is obvious that OSLE have positive effects in increasing motivation of students. For example, Çavuş, Kaplan, Sünbül and Çetin (2010), examined the impact of OSLE on motivation and attitudes of students toward science and technology course. The results indicated that motivation and attitude scores of the students who participated in out-of-school activities in Science and Technology Club were significantly higher than those who did not. Kulalıgil and Bağ (2014) investigated the effect of teaching in OSLE on students' motivation for and success in science learning in the fifth-grade unit "Let's Explore and Learn the World of Living Creatures". The study results showed that OSLE increased students' motivation for and success in science learning more than the classroom environment. Sim (2015) investigated students' experiences in 3 different informal learning environments (museum, exhibition of livestock, and environment centers) to understand and identify the learning realized in these environments. The study reported that discovering OSLE was a source for increasing students' motivation. Paris, Yambor and Packard (1998) studied the effect of out-of-school practices on students' interest and knowledge about biology. The study showed that students' levels of interest, problem-solving skills, and motivation increased in biology. Ramey-Gassert (1997) discussed that learning in OSLE sparked a desire for learning, and also helped learners develop attitudes and motivation for learning. Falk and Adelman (2003), Lukas and Ross (2005) stated that zoos drew students' interest and attention and promoted their attitudes and motivation for the course.

The study conducted by Taşdemir, Kartal and Kuş (2012) was found that OSLE had a positive effect on science attitudes of students. This result was explained with the fact that activities performed in science museums which are among OSLE, established a connection between science and daily life. Çı̆grı (2016) investigated the effect of learning activities in science centers, one of the out of learning environments, on science course success, attitudes, and motivation of the seventh-grade students. The experiment group performed learning activities in the science center for four weeks, while the control group did so in the laboratory. As a 
result of the study, learning activities in science centers were found to have significant effect on students' attitudes, motivation, and success. This result was explained with the fact that students concretized abstract concepts and learned by practicing with the group while performing activities in the science center. Bodur (2015) investigated the effect of out-ofschool activities on seventh grade students' success, scientific process skills, and motivation for science learning. The control group attended regular courses whereas the experiment group participated in out-of-school activities in the science and experiment centre for two course hours per week for four weeks, which supported the curriculum. The results showed that the experiment group had higher scores in motivation for scientific process skills and science learning. This result was explained with the fact that students were able to learn by observing celestial bodies which are amongst science lesson subjects, as well as by practicing, experiencing and having fun at the planetariums and observatories they visited. At the end of the visit to the wind plant, Balkan Kıyıcı and Atabek Yiğit (2010) determined that pre-service science teachers had positive views on OSLE. This result was explained with the fact that OSLE provided a first-hand experience and enabled pre-service teachers to have a good time at the wind plant, to do observations and learn the subject better. Bakioğlu and Karamustafaoğlu (2014) concluded that the visit to the dialysis center raised the awareness of organ donation of 7 th grade students. This result was explained with the fact that the visit to OSLE enabled students to do observations, experience the subjects in real life and learn by having fun. Kulaligil (2015) determined that teaching performed in OSLE had a significant contribution to the development of $5^{\text {th }}$ grade students' motivation. This result was explained with the fact that the visits to OSLE like the zoo and waste paper collection and separation center, attracted students' attention, aroused their interest, increased their desire to learn the subject and reduced their anxiety. Güler (2011) determined that a planned museum visit would make a positive contribution to students' attitudes toward the lesson. This result was explained with the fact that students attended activities in the museum by practicing. The abovementioned explanations about the reasons of the positive effect of OSLE on affective properties support the effect of learning-teaching activities performed in OSLE on motivation development in this study.

These studies support the present study reporting that OSLE have a positive effect on increasing motivation. However, the common characteristic of the above-mentioned studies was that out-of-school trips were organized once or several times in three to four weeks, but the permanence of the increase in motivation was not investigated. Another interesting result obtained from these studies was that motivation, a kind of affective property which can be generated in the long-term, was promoted in a short period of time such as 3-4 weeks. This study differs from others as it is sufficiently long to allow for the promotion of affective properties like motivation, since it makes visits to OSLE regarding any subject taught in the curriculum, and it examines whether the change in motivation is permanent or not. Examining the change in motivation using a follow-up test is important in terms of determining whether the effect of OSLE on motivation is of permanent sort. These differentiate this study from the other studies found in the literature and attach more importance to it.

In the study by Benton (2013), science course trips were organized for fifth grade students to increase their grades, interest in science, and provide education in a natural environment. The students took part in a program lasting for 6 months which include activities performed once a month. The results showed that the students had higher grades compared to the previous academic year. Furthermore, 93 students were interviewed before and after the trip. The trips proved to be important factors for increasing internal motivation. Studies in the literature such as those conducted by Braund and Reiss (2006), Dohn (2013), Hofstein and Rosenfeld (1996), 
Rowe and Nickels (2011), Stavrova and Urhahne (2010), Thompson and Bennett (2013); Watson, Dod and Jones (2007); Wellington (1990) support the idea that learning environments enriched by the inclusion of OSLE in the curriculum increase students' motivation. Ramey-Gassert et al. (1994) reported that out-of-school environments increase students' desire to learning, attitudes, and motivation for learning and contribute to their socialization. There are also studies (Bostan Sarıŏlan \& Küçüközer, 2017; Şentürk \& Özdemir, 2014; Wulf, Mayhew \& Finkelstein, 2010) indicating that OSLE also have a positive effect on attitudes toward science course, which is an affective property like motivation.

To put it in a nutshell, the current study showed that visits made to OSLE increased students' motivation and helped them maintain their motivation for science learning in the experiment group, whereas science education offered based on the curriculum only was not effective on students' motivation. This results from the fact that by establishing OSLE teaching process is not limited within the school walls, it is moved out of the school, and these environments offer rich learning environments from real life with real objects, allow students to interact with real phenomena, events, and objects, enable to experience knowledge and transfer it to real life, and ensure learning by arousing students' curiosity whilst having fun. For instance, during the visit to the planetarium which is among OSLE, it was observed that watching the simulations of celestial bodies and observing them through a telescope in the observatory, attracted students' attention, aroused their interest and enabled them to learn by having funpracticing-experiencing, to establish a connection between science and real life and to have a good time outside school. It was seen that students were able to perceive and understand the subjects of "Solar System and Beyond" more easily by means of using the POE technique while observing celestial bodies during planetarium and observatory visits, as well as sharing and discussing the observations in the classroom and attaining generalizations. It is possible to state that these activities which are performed in out-of-school science teaching motivate students to learn science. Based on the fact that OSLE contribute to an increase in motivation which is an important affective property for teaching science, the curriculum should include these environments that can enrich learning being motivating factors for students, drawing attention and assuring learning by having fun, allowing students to experience the phenomena, events, concepts, and principles of outside world. It is suggested that trips for out-of-school teaching purposes be organized in parallel with the gains in the curriculum. Science that is all about life itself is limited to formal teaching environments in general since no trips related to the objectives of the curriculum are included in the programs. However, the concepts, phenomena, and events happen outside the classroom. Science learning that is not associated with real life will not reach its goals. Thus, it is necessary to consider the objectives of a course and not to limit them with the school walls, and enrich teaching science by the visits to OSLE in order to associate science courses with real life.

Other studies in the literature such as Çı̆grık (2016), Stocklmayer et al. (2010), Y1ldırım (2018a), Y1ldırım (2018b) also stated that informal education should likewise be included in formal education. This is because learning environments taken outside the classroom allow students to interact with real phenomena, events, and objects in outside life by offering them rich learning environments, help them practice their knowledge and transfer it into daily life, and keep alive their curiosity, interest, attitudes, and motivation which are described as affective properties (Bozdoğan, 2018; Çı̆̆rık, 2016; Laçin Şimşek, 2011; Pedreti, 2006; Y1ldirım, 2018a). Supporting this finding, a study conducted by Rennie (2007) indicated that out-of-school learning, compared to formal learning, is not teacher-centered or an external motivator but student-centered and an internal motivator. 
Including teachers and students with whom the researcher can easily communicate, whose classes he could direct, monitor, follow and visit, whose during trips to learning environments which are out of school for teaching science he could accompany, that is, trying to resort to the most appropriate sample is a limitation of the study. To eliminate this limitation, further studies can be conducted using sampling methods like simple random sampling.

\section{References}

Akcan, S. (2010). Outdoor school environmental education in social sciences. (Unpublished master's thesis). University of Abant İzzet Baysal, Bolu.

Atmaca, S. (2012). Outdoor education activities in science education and effects of these activities on pre-service teachers. (Unpublished doctoral dissertation). University of Hacettepe, Ankara.

Bakioğlu, B. (2017). Effectiveness of out-of-school learning setting aided teaching of the $5^{\text {th }}$ grade let's solve the riddle of our body chapter. (Unpublished doctoral dissertation). University of Amasya, Amasya.

Bakioğlu, B., \& Karamustafaoğlu, O. (2014). Outdoor science education: Technical visit to a dialysis center. Turkish Journal of Teacher Education, 3(2), 15-26.

Balkan Kıyıc1, F., \& Atabek Yiğit, E. (2010). Science education beyond the classroom: A field trip to wind power plant. International Online Journal of Educational Sciences, 2(1), 225-243.

Behrendt, M., \& Franklin, T. (2014). A review of research on school field trips and their value in education. International Journal of Environmental and Science Education, 9(3), 235- 245. doi: 10.12973/ijese.2014.213a

Benton, G. M. (2013). The role of intrinsic motivation in a science field trip. Journal of Interpretation Research, 18(1), 71-82.

Binbaşıŏlu, C. (2000). Okulda ders dışı etkinlikler [Extracurricular activities at school]. İstanbul: Milli Eğitim Publishing.

Bodur, Z. (2015). The effect of outdoor class activities in the solar system and beyond unit on seventh grade student's academic achievements, scientific process abilities and motivation. (Unpublished master's thesis). University of Marmara, İstanbul.

Bostan Sarığlan, A., \& Küçüközer, H. (2017). Investigation of pre-service science teachers' opinions regarded to outdoor school learning environments. Journal of Research in Informal Environments (JRINEN), 2(1), 1-15.

Bozdoğan, A. E. (2012). The practice of prospective science teachers regarding the planning of education based trips: Evaluation of six different field trips. Educational Sciences: Theory \& Practice, 12(2), 1050-1072.

Bozdoğan, A. E., Okur, A., \& Kasap, G. (2015). A sample application for a planned field trip: A factory trip. The Black Sea Journal of Social Sciences, 7(14), 1-12.

Bozdoğan, A.E. (2007). Role and importance of science and technology in education. (Unpublished doctoral dissertation). University of Gazi, Ankara.

Bozdoğan, A.E. (2018). Science education outside school. In A. Tekbıyık \& G. Çakmakçı (Eds.). Science teaching and STEM activities (pp. 369-394). Ankara, Nobel Publishing.

Braund, M., \& Reiss, M. (2006). Towards a more authentic science curriculum: The contribution of out-of-school learning. International Journal of Science Education, 28(12), 1373-1388.

Büyüköztürk, S. (2016). Sosyal bilimler için veri analizi el kitabı, istatistik, araştırma deseni, SPSS uygulamalarl ve yorum [Data analysis handbook for social sciences, statistics, research design, SPSS applications and comments]. Ankara: Pegem Publishing. 
Büyüköztürk, S., Kılıç Çakmak E., Akgün, O. E., Karadeniz, S., \& Demirel, F. (2016). Bilimsel araştırma yöntemleri [Scientific research methods]. Ankara: Pegem Publishing.

Cantürk Günhan, B., \& Başer, N. (2008). The effect of problem based learning on students' attitudes towards and achievements in mathematics. Journal of Abant Izzet Baysal University Faculty of Education, 8(1), 119- 134.

Çavuş, R., Kaplan, A., Sünbül, F., \& Çetin, B. (2010). The effect of out-of-school learning environments on students' attitude and motivation towards science and technology lesson: Kocaeli Science and Technology Club case. IX. National Science and Mathematics Education Congress, University of Dokuz Eylül, İzmir.

Çebi, H. (2018). Effect of different extracurricular learning environment on students' attitudes and interest in science course. (Unpublished master's thesis). University of Y1ld1z Teknik, İstanbul.

Chin, C-C. (2004). Museum Experience: a Resource for Science Teacher Education. International Journal of Science and Mathematics Education, 2, 63-90.

Çı̆̆rık, E. (2016). The effect of science center learning activities on students' science achievement and attitude (Unpublished doctoral dissertation). Uludağ University Institute of Educational Sciences, Bursa.

Çığrık, E., \& Özkan, M. (2016). The effect of science center learning activities on students' science achievement and relationship with motivation level. Journal of Uluda $\breve{g}$ University Faculty of Education, 29 (2), 2016, 279-301.

Cohen, J. (1988). Statistical power analysis for the behavioral sciences, Hillsdale, NJ: Lawrence Earlbaum Associates.

Dede, Y., \& Yaman, S. (2008). A questionnaire for motivation toward science learning: A validity and reliability study. Necatibey Faculty of Education Electronic Journal of Science and Mathematics Education, 2(1), 19-37.

Dohn, B. (2013). Upper secondary students' situational interest: A case study of the role of a zoo visit in a biology class. International Journal of Science Education, 35(16), 27322751.

Ertaş, H., \& Şen, A. I. (2017). Out-of-school learning environments in physics teaching. In A. I. Şen \& A.R. Akdeniz (Eds.). Physics teaching (pp. 413-444). Ankara: Pegem Publishing.

Ertaş, H., Şen, A. I., \& Parmaksızoğlu, A. (2011). The effects of out - of school scientific activities on $9^{\text {th }}$ grade students' relating the unit of energy to daily life. Necatibey Faculty of Education Electronic Journal of Science and Mathematics Education, 5(2), 178-198.

Erten, Z. (2016). Development of out-of-school learning activities regarding in science curriculum and evaluation of the effects of scientific processes skills of students. (Unpublished master's thesis). University of Erzincan, Erzincan.

Falk, J. H, Needham, M. D., Dierking, L. D., \& Prendergast, L. (2014). International science centre impact study final report. Retrieved from https://www.pavconhecimento.pt/media/media/1832_iscis-final-report.pdf

Falk, J.H., \& Adelman, L.M. (2003). Investigating the impact of prior knowledge and interest on aquarium visitor learning. Journal of Research in Science Teaching, 40(2), 163176.

Falk, J.H., \& Needham, M. (2011). Measuring the impact of a science center on its community. Journal of Research in Science Teaching, 48(1), 1-12.

Fried Hoffer, B. (2007). Why an informal science intervention. Maxwell Auditorium, Singapore. 
Griffin, J. (2004). Research on students and museums: Looking more closely at the students in school groups. Science Education, 88(1), 59-70.

Guisasola, J., Solbes, J., Barragues, J. I., Morentin, M., \& Moreno, A. (2009). Students understanding of the special theory of relativity and design for a guided visit to a science museum. International Journal of Science Education, 31(15), 2085-2104.

Guisasola, J., Morentin, M., \& Zuza, K. (2005). School visits to science museums and learning sciences: A complex relationship. Physics Education, 40(6), 544-549.

Güler, A. (2011). Impact of a planned museum tour on the primary school students' attitudes. Elementary Education Online, 10(1), 169-179.

Güvercin, O., Tekkaya, C., \& Sungur, S. (2010). A cross age study of elementary students' motivation towards science learning. Hacettepe University Journal of Education, 39, 233-243.

Hofstein, A., \& Rosenfeld, S. (1996). Bridging the gap between formal and informal science learning. Studies in Science Education, 28, 87-112.

Katz, P., McGinnis, R., Hestness, E., Riedinger, K., Marbach, G., Dai, A., \& Pease, R. (2011). Professional identity development of teacher candidates participating in an informal science education internship: A focus on drawings as evidence. International Journal of Science Education, 33(9), 1169-1197.

Kete, R., \& Horasan, Y. (2013, September). Pre-service teachers' productivity in applied biology courses. VI. National Graduate Education Symposium Proceedings II, University of Sakarya, Sakarya.

Kulaligil, A. (2015). The effect of teaching practices occurring in out-of-class teaching environments on academic success, creativity and motivation of fifth grade science class students. (Unpublished master's thesis). University of Pamukkale, Denizli.

Kulalıgil, A., \& Bağ, H. (2014, September). The effect of teaching practices in out-of-school learning environments on motivation and academic success of students. XI. National Science and Mathematics Education Congress Abstract Booklet. Çukurova University Educational Faculty, Adana.

Laçin Şimşek, C. (2011). Out-of-school learning environments and science education. In C. Laçin Şimşek (Eds.). Out-of-school learning environments in science teaching (pp. 123). Ankara: Pegem Publishing.

Lazowski, R. A., \& Hulleman, C. S. (2016). Motivation interventions in education: A metaanalytic review. Review of Educational Research, 86(2), 602-640.

Lukas, K. E., \& Ross, S. R. (2005). Zoo visitor knowledge and attitudes toward gorillas and chimpanzees. The Journal of Environmental Education, 36(4), 33-48.

Ministry of National Education (MNE). (2013). Curriculum of elementary schools science teaching $(3,4,5,6,7$ and 8 th grades $)$. Retrieved from http://ttkb.meb.gov.tr/www/guncellenen-ogretim-programlari/icerik/151

Ministry of National Education (MNE). (2017). Curriculum of science course teaching. Retrieved from http://mufredat.meb.gov.tr/ProgramDetay.aspx?PID=143

National Research Council. (2009). Learning science in informal environments: People, places, and pursuits. Washington, DC: National Academies Press.

Paris, S. G., Yambor, K. M., \& Packard, B. W. (1998). Hands-on biology: A museum schooluniversity partnership for enhancing students' interest and learning in science. The Elementary School Journal, 98(3), 267-288.

Pedretti, E. (2006). Editorial: Informal science education: Critical conversations and new directions. Canadian Journal of Science, Mathematics and Technology Education, $6(1), 1-4$.

Ramey Gassert, L. (1997). Learning science beyond the classroom. The Elementary School Journal, 97(4), 433-450. 
Ramey-Gassert, L., Walberg, H., \& Walberg, H.J. (1994). Museums as science learning environments: Reexamining connections. Science Education, 78(4), 345-363.

Randler, C., Kummer, B., \& Wilhelm, C. (2012). Adolescent learning in the zoo: Embedding a non-formal learning environment to teach formal aspects of vertebrate biology. Journal of Science Education and Technology, 21(3), 384-391.

Rennie, L. J. (2007). Learning science outside of the school. In S. K. Abell \& N. G. Lederman (Eds.), Handbook of research on science education (pp. 125-167). New Jersey: Lawrence Erlbaum Associates.

Rowe, S., \& Nickels, A. (2011). Visitor motivations across three informal education institutions: An application of the identity-related visitor motivation model. Visitor Studies, 14(2), 162-175.

Salmi, H. (1993). Science centre education, motivation and learning in informal education. (Unpublished doctoral dissertation). University of Helsinki, Helsinki.

Selçuk, Z. (2015). Eğitim Psikolojisi [Education psychology]. Ankara: Nobel Publishing.

Sim, G. (2015). Learning about biodiversity: Investigating children's learning at a museum, environment centre and a live animal show. (Unpublished doctoral dissertation). University of London, London.

Smith, E. F., Steel, G., \& Gidlow, B. (2010). The temporary community: Student experiences of school-based outdoor education programs. Journal of Experiential Education, 33(2), 136-150. doi: 10.1177/105382591003300204

Sözer, Y., \& Oral, B. (2016). Supplementary active outdoor learning process for classroom learning: A meta-synthesis study. International Journal of Eurasia Social Sciences, 7(22), 278- 310.

Stavrova, O., \& Urhahne, D. (2010). Modification of a school programme in the deutsches museum to enhance students' attitudes and understanding. International Journal of Science Education, 32(17), 2291-2310.

Stocklmayer, S., \& Gilbert, J. (2003). Informal chemical education in international handbook of science education. Part one. Netherlands: By Kluwer Academic Publishers.

Stocklmayer, S.M., Rennie, L.J., \& Gilbert, J.K. (2010). The roles of the formal and informal sectors in the provision of effective science education. Studies in Science Education, 46(1), 1-44.

Şentürk, E., \& Özdemir, O. F. (2014). The effect of science centers on students' attitudes towards science. International Journal of Science Education, Part B, Communication and Public Engagement 4(1), 1-24.

Taşdemir, A., Kartal, T., \& Kuş, Z. (2012). The use of out-of-the-school learning environments for the formation of scientific attitudes in teacher training programmes. Procedia - Social and Behavioral Sciences, 46, 2747 - 2752.

Taşoğlu, M. (2010). Activities outside school teaching geography of the student's academic effects of success. (Unpublished master's thesis). University of Marmara, İstanbul.

Tatar, N., \& Bağrıyanık, K. E. (2012). Opinions of science and technology teachers about outdoor education. Elementary Education Online, 11(4), 883-896.

Thompson, G. H., \& Bennett, J. (2013). Science teaching and learning activities and students' engagement in science. International Journal of Science Education, 35(8), 1325-1343.

Topçuoğlu Ǘnal, F., \& Bursalı, H. (2013). Turkish teachers views about motivation factors. Middle Eastern \& African Journal of Educational Research, 5, 7-22.

Türkmen, H. (2010). Historical overview of informal (out-of-school) science education and integration to education. Çukurova University Faculty of Education Journal, 3 (39), 46-59.

Türkmen, H. (2018). Perspectives of secondary school teachers about out-door teaching. Journal of Ege Social Science, 1(1), 12- 26. 
Uzun, N., \& Keleş, Ö. (2012). Evaluation of primary school students' motivation levels for science learning. Mustafa Kemal University Journal of Social Sciences Institute, 9(20), 313-327.

Watson, S., Dod, J., \& Jones, C. (2007). Engage, learn, achieve: The impact of museum visits on the attainment of secondary pupils in the East of England 2006-2007. Retrieved from https://le.ac.uk/rcmg/research-archive/engage-learn-achieve

Wellington, J. (1990). Formal and informal learning in science: The role of the interactive science centers. Physics Education, 25(5), 247-252.

Wulf, R., Mayhew, L. M., \& Finkelstein, N. D. (2010, July). Impact of informal science education on children's attitudes about science. Physics Education Research Conference, Portland, Oregon, AIP Conference Proceedings, 1289, 337-340.

Yavuz Topaloğlu, M. (2016). The effect of out-of-school learning environments based on socio-scientific issues on students' conceptual understandings and decision-making skills. (Unpublished doctoral dissertation). University of Sakarya, Sakarya.

Yıldırım, H.İ. (2018a). The impact of out-of-school learning environments on 6th grade secondary school student's attitude towards science course. Journal of Education and Training Studies, 6(12), 26-41.

Y1ldırım, H.İ. (2018b). The effect of science fairs on the 6th grade students' problem solving skills. Trakya Journal of Education, 8(2), 390-409.

Y1ldırım, H.İ., \& Karataş, F. (2018). Investigation of secondary school students' motivation toward science learning according to some variables. The Journal of Academic Social Science, 65, 164-187. 